\title{
On the Impact of School Teacher Fellows in Chemistry Departments within UK Higher Education Institutes, from 2005-2013
}

\author{
Dudley E. Shallcross ${ }^{1}$, Timothy G. Harrison ${ }^{1}$, David Read ${ }^{2}$ \& Nicholas Barker ${ }^{3}$ \\ ${ }^{1}$ School of Chemistry, University of Bristol, UK \\ ${ }^{2}$ Department of Chemistry, University of Southampton, UK \\ ${ }^{3}$ Department of Chemistry, University of Warwick, UK \\ Correspondence: Dudley Shallcross, School of Chemistry, Cantock’s Close, University of Bristol, BS8 1TS, UK. \\ Tel: 44-117-928-7796. E-mail: d.e.shallcross@bris.ac.uk
}

Received: May 1, 2014 Accepted: June 20, 2014 Online Published: July 29, 2014

doi:10.5539/hes.v4n4p7 URL: http://dx.doi.org/10.5539/hes.v4n4p7

\begin{abstract}
Two UK programmes to place school teachers in a university setting are compared; the Excellence Fellowship Awards Pilot Scheme and the School Teacher Fellows Scheme. In this paper we compare the School Teacher Fellow Scheme supported by Bristol ChemLabS (Shallcross et al., 2013a, 2013b) and subsequently by the Royal Society of Chemistry with the Excellence Fellowship, focussing on the recruitment and support of fellows and their impact on transition from secondary to tertiary education, secondary school chemistry teaching, tertiary teaching of chemistry in general, and then more specific impacts on their own teaching and career. Examples of the work undertaken by the School Teacher Fellows are noted.
\end{abstract}

Keywords: excellence fellowship awards pilot, school teacher fellows, transition

\section{Introduction}

\subsection{Background}

The willingness for science departments in Higher Education Institutions (HEIs) to have experienced secondary school teachers working within them as Fellows is not a new idea. The Excellence Fellowship Awards Pilot Scheme was launched in the U.K. in February 2002 by the then Department for Education and Skills (DES) and was to run for two years (Marwood, 2004). The scheme was set up to enable teachers to spend a term away from school or further education college and in an Higher Education Institute. Teachers were expected to use this time to undertake a project that had a direct bearing on encouraging progression to Higher Education among their students. The precise details of the relationship between teacher and Higher Education Institute and the project undertaken were left to the individuals to arrange. In total around 70 Fellows were recruited over the two year period (short of the target of 100), who were mainly (85\%) senior staff. Only 17 out of 70 Fellows were full-time for one term, the rest were part-time. Recruitment was not easy, mainly because of difficulties arranging teacher cover at their school, whilst on the fellowship. Competition for places was not strong and it is reported that 'low quality' bids were occasionally accepted. Only 9 reports from 43 completed fellowships (at the time of the evaluation report) were received and the overall conclusion was that while there were a few good projects that emerged, in the majority of cases limited impact had occurred.

There is no doubt that placing secondary school teachers in a tertiary (University) education department has many potential benefits to the teacher, their school and the tertiary institute (Shallcross \& Harrison, 2007a, 2007b). However, given the low success rate of the Excellence Fellowship Scheme, as measured against its own stated objectives, embarking on such a program would seem to be difficult.

\subsection{The School Teacher Fellow Scheme}

\subsubsection{Background to CETLs and Bristol ChemLabS}

The School Teacher Fellow concept as described in this paper was a central component of the Bristol ChemLabS CETL (Centre for Excellence in Teaching and Learning) in Chemistry (Harrison \& Shallcross, 2010a; Harrison et al., 2011a; Shallcross et al., 2006a; Shallcross et al., 2007c; Shallcross et al., 2013a, 2013b; Shaw et al., 2011) and in particular the Outreach component of that CETL. The CETL initiative is described in several papers 
(Chalkley, 2006; Lambourne, 2007; Morales and Carmichael, 2007; Clouder et al., 2008; Shallcross et al., 2013a) and the CETL project summary report (SQW, 2011) and will only be briefly summarised here. In 2005 the Higher Education Funding Council for England (HEFCE) established 74 CETLs in Higher Education Institutes in England and these were spread across all subjects and many cross disciplinary themes. The School of Chemistry at Bristol University was the only centre to be awarded a CETL (Bristol ChemLabS) devoted to practical chemistry. In addition to the refurbishment of the teaching laboratories and a major overhaul to the practical course, two elements were prominent; the development of a Dynamic Laboratory Manual (DLM) for undergraduate chemistry teaching, which has been extended to A level chemistry (post-16) and foundation degree studies (Norman, 2007; Harrison et al., 2009a, 2012a; Shallcross et al., 2013a, 2013b) and the substantial expansion of the Outreach activities to schools, teachers and the general public leading to a financially sustainable (independently funded from the CETL and University) operation (Harrison et al., 2009b, 2010b, 2010d; Harrison \& Shallcross, 2007b 2010a, 2010c; Shaw et al., 2009, 2010a, 2010b,, 2010c, 2011; Tuah et al., 2009, 2010).

\subsubsection{Genesis of the School Teacher Fellow}

Over a five year period of working with secondary school teachers (2000-2005) to establish links between the School of Chemistry at the University of Bristol and UK secondary schools in the region, the School's Liaison Officer set up a network of U.K. Chemistry teachers called CHeMneT (http://www.chemlabs.bris.ac.uk/outreach/chemnet/). It soon emerged that in order to take the partnership further seconding a secondary school teacher was needed to work in the School of Chemistry with the School's Liaison Officer. Through the award of the CETL (Bristol ChemLabS; Shallcross et al., 2013a), monies were available to the School's Liaison Officer (now Outreach Director) to establish a School Teacher Fellow post for up to five years in the first instance (2005-2010). The initial role of the School Teacher Fellow as outlined in previous papers (Shallcross \& Harrison, 2007a, 2007b) was to review the congruence between post-16 courses (predominantly the A level in the UK) and first year undergraduate courses in Chemistry, both lectures and practicals and to work with the Outreach Director to expand the Outreach programme to secondary schools and colleges.

On the recommendation of Bristol ChemLabS, the School Teacher Fellow scheme was adopted by the Royal Society of Chemistry (RSC) initially as part of its programme Chemistry: The Next Generation (C:TNG; Lord et al, 2008) and then Chemistry for our Future (CFOF; Tunney, 2009; Read, 2010a) and most recently through the UK National HE STEM initiative (http://www.rsc.org/Education/EiC/issues/2011September/schoolteacherfellows.asp). In addition, two School Teacher Fellows were funded as part of a project with AstraZeneca PLC. In all, 17 School Teacher Fellows have been recruited by the RSC up to 2011 (Table A), with no recruitment in 2012 or 2013.

The Institute of Physics has also recognised the value of placing teachers in university departments. The "Teacher Fellowship Scheme" (IOP, 2010) placed 12 seconded teachers in 10 university departments between May 2006 and July 2009. The project was funded through the HEFCE Stimulating Physics Programme. The main aim was to "forge and foster stronger links between schools and university through the formation of partnerships between school and local university.” A secondary aim was to enhance the quality of outreach activity. The document produced also gave advice to university departments that were considering implementing a Teacher Fellowship Scheme.

\section{Comparisons between the Excellence Fellowship and the School Teacher Fellow Scheme}

\subsection{Recruitment}

The evaluation of the Excellence Fellowship (Marwood, 2004) suggests that recruitment was very variable in terms of success. First, the objectives of the scheme were unclear to teachers, their schools and the proposed institutes. Therefore, teachers were not clear what the scheme was about and as a result they did not apply. Second, even if a teacher was interested and was allowed by their school to apply, they were not clear what a suitable theme for the project might be. Although the Fellowship scheme intended to increase progression of students in the Fellow's school to Higher Education Institutes, the word 'Fellowship' suggested something to enhance the teacher's own progression. Third, it appears that it was difficult for schools to release teachers for a term and find suitable teacher cover. Finally, the concept of competitive recruitment was non-existent.

The School Teacher Fellow scheme described here was focused on one subject (Chemistry) rather than the myriad subjects offered by the Excellence Fellowship scheme. School Teacher Fellows recruited by Bristol ChemLabS had already been working with the School of Chemistry at Bristol University (through its own secondary school teacher network called CHeMneT, founded in 2000) for five years. So here at least there was 
already a strong contact between a Higher Education Institute and teacher. For the Royal Society of Chemistry led scheme, shortlisted applicants (from a widely advertised scheme) were called for interview and examples of work from Bristol ChemLabS were presented to perspective recruits. Therefore, applicants could gauge what the School Teacher Fellow scheme was about and were able to talk with fellow teachers about the scheme. There was no problem attracting high quality applicants to the School Teacher Fellow scheme. The shortlisted candidates were interviewed and the successful ones were placed with their nearest participating Higher Education Institute. The Royal Society of Chemistry was well placed to act as the broker in the School Teacher Fellow scheme and dealt with contracts and provided much needed administrative support. The majority of posts were for a full year with some term secondments being trialled. The recruitment of excellent School Teacher Fellows in year 1 of the Royal Society of Chemistry scheme allowed it to self perpetuate, current and former School Teacher Fellows were able to discuss the role with new potential applicants. The new School Teacher Fellows had an induction day with current School Teacher Fellows, their new Higher Education Institute partner and the Royal Society of Chemistry. First, the School Teacher Fellows were able to meet each other and exchange plans for the year, new Higher Education Institute liaisons were able to meet existing ones and share information and plans about how best to support the School Teacher Fellows and it provided an opportunity for the whole group to share plans and expectations for the coming year, something totally missing from the Excellence Fellowship scheme. For at least one School Teacher Fellow the fact that there was no brief was the big attraction in taking the position.

Focusing on one subject, providing clear guidelines about the scheme, having a clear recruitment policy, establishing liaison within the host Higher Education Institute, allowing all partners to meet and form contacts at the start, and having an independent body managing the whole scheme was a far more effective strategy than that provided by the Excellence Fellowship scheme.

\subsection{The Incentives for Wanting to Take Part in The Scheme; The Teacher}

There are many reasons why a committed secondary schoolteacher might apply for a one year secondment to a Higher Education Institute under the Royal Society of Chemistry School Teacher Fellow scheme. Discussions with potential applicants and interviews for posts reveal that reasons include; wanting a respite from the pressures of school, to look good on a CV for future promotions, to re-energise their passion for chemistry and hopefully have fun as well as a new challenge, but for most to experience effective teaching in a completely different way to normal examination-driven classroom chemistry using the phenomenal resources of the UK's major chemistry departments. As one early School Teacher Fellow commented:

"From the outset I was told that it was 'my fellowship' and I could do whatever I liked. Frustrated by the testing culture so prevalent in schools I wanted to share the resources of this Chemistry Department with school children and teachers. My belief was that this would inspire and invigorate people to see the beauty inherent in science, to be inspired by working with talented professionals and to gain the satisfaction of completing challenging tasks in an unfamiliar environment.'

There are a lot of teachers who have an interest in the programme, but many are reluctant to leave their school, albeit for a single year. Some worry that they might lose their edge while they are away, and others feel that they might become slightly out of touch, bearing in mind the rapid pace of change with regard to curricula and the latest 'in vogue' teaching approaches at school level.

\subsection{The Incentives for Wanting to Take Part in The Scheme; The School}

Taking up a position as a seconded School Teacher Fellow also holds difficulties for the management of the schools releasing the teachers for a year. Some school head teachers were reported to be reluctant to lose their best chemistry teachers for many reasons including the difficulty in finding a suitably qualified cover teacher for the year. It should be noted that some School Teacher Fellows resigned from their teaching posts to take up the position. However, there are myriad reasons for supporting an application and those noted by senior management include all the reasons given by the Fellows in section 2.2. but in addition, from a management viewpoint there was prestige attached to the position, the opportunity to engage closely with a Higher Education Institute and in some schools this was an opportunity to give younger staff management experience, even if only for a year. There was also the possibility of having access to resources and the development of a longer term relationship between the host school and Higher Education Institute.

\section{What use is a STF to a department? Examples of Projects undertaken and their impact}

The initial group of 7 full and part time School Teacher Fellows, funded by the Royal Society of Chemistry (http://www.rsc.org/Education/EiC/issues/2007July/TeacherFellowsGoToUniversity.asp) through the CFOF 
project were charged to:

- discover how chemistry is taught to undergraduates through lectures, tutorials and practical work observation,

- $\quad$ improve lecturers' knowledge of both GCSE science and Post 16 chemistry course content (Read \& Harrison, 2010c) and teaching styles used in schools,

- $\quad$ help host departments to further develop outreach activities for students and teachers.

The main aims were to modify the first-year undergraduate experience, to better the skill set and experiences of future students and to improve outreach activity provision. Elements of these tasks are still given to new School Teacher Fellows as they work with departments themselves new to working with School Teacher Fellows. A flavour of outputs from some School Teacher Fellows, showing how the initial and other aims were achieved:

(a) An update of the changes in course content, across several examination boards, for ' $A$ ' level chemistry with updates due to specification (syllabus) changes (Read \& Harrison, 2010c).

(b) The better use of undergraduate teaching laboratories in the promotion of chemistry (Harrison, 2011a).

(c) Festivals of Contemporary Science for Teachers (Harrison et al, 2010e) was set up as a support for science teachers in the south of England and Wales, as subject specific, rather than pedagogical continued professional development (CPD).

(d) Making leading edge science research available to a wide range of school students and their teachers by working with researchers and writing articles in an appropriate level of language linked to schools' curricular [Appendix].

(e) Contributions to national projects include: materials contributed to the RSC's Spectroscopy in a Suitcase (SIAS) project by several School Teacher Fellows (http://www.rsc.org/Education/HESTEM/SIAS.asp) and the Chemistry in Your Shopping Basket resource (Willis \& Hoare, 2009). The latter as part of the legacy of the C:FOF funded Strand 1: School Teacher Fellows (http://www.rsc.org/Education/CFOF/Strand1.asp).

(f) Changes to the tutorial system of a chemistry department following work with the first year chemistry cohort to ascertain their background and learning experiences.

(g) The development of practical courses or components in support of undergraduate practical work, (Robson, 2011).

(h) The implementation of action research projects, where innovations are trialled and evaluated, providing academics with the evidence to encourage the adoption of the innovation in question (for an example, see Boniface et al., 2011).

(i) Evaluating university application visits in its entirety (Bagshaw et al., 2011).

An excellent and detailed illustration of the value of School Teacher Fellows in transferring innovation across the school-university interface was the introduction of electronic voting systems into teaching (Page \& Read, 2010) at Southampton. Unlike traditional Q\&A, which typically engages only a small proportion of a class, this technology allows the teacher to probe the views of the entire cohort. This is particularly important during the crucial "transition phase", when students' confidence levels tend to be lower. The use of electronic voting systems allows students to demonstrate their level of understanding in an anonymous fashion, and allows teachers to provide rapid feedback at the point of need. This aspect of the work done at Southampton has perhaps gained a higher profile by virtue of the fact that it was implemented by a School Teacher Fellow, and similar approaches have been adopted by School Teacher Fellows elsewhere.

The outcomes of this particular work at Southampton have also had an impact at pre-university level, with electronic voting systems being extensively employed in the delivery of outreach work. As well as facilitating the "edutainment" aspect of outreach delivery (Niyadurpola \& Read, 2008), the use of electronic voting systems also breaks down some of the communication barriers that exist in traditionally didactic Higher Education teaching situations such as lectures. This technology also has applications in the school classroom, (Read, 2010b) and the School Teacher Fellow has worked with colleagues in local schools and colleges to widen the usage of voting systems and to facilitate their adoption through the development of Continuing Professional Development events.

More recently, teaching at Southampton has been enhanced by the work of the School Teacher Fellow in the deployment of video resources across the chemistry programme. Students have reported the benefits of recorded 
lectures in supporting their learning (Andrews et al., 2010), whilst related work on screencasts has led to collaborations with other Higher Education Institutes. The outputs of this work have been disseminated widely, both in Higher Education and at school level (Lancaster \& Read, 2011; Read \& Lancaster, 2012). Video technology has also been used to support the delivery of self-assessment exercises, with evidence indicating that this approach has significantly enhanced learning (Brown et al., 2012). The use of video resources has enhanced activity in the area of 'flipped teaching', where didactic content delivery is moved online to free up precious face-to-face time for different modes of interactive teaching (Lancaster \& Read, 2013). The 'flipped teaching project has been of great interest to teachers in schools and colleges locally, and has sparked a wave of new collaborations. The support for students in mathematics and physics who do not have a post-16 qualification in mathematics has benefitted greatly from School Teacher Fellow involvement, where the perspective of a former school teacher has been invaluable. It should also be noted that mathematics summer schools run under the auspices of the Royal Society of Chemistry have also benefitted from School Teacher Fellow input (Shallcross et al., 2011).

\section{Recommendations}

\subsection{Recruitment Strategy}

There is no doubt that a good recruitment strategy is vital and that there are successful examples of the scheme that can be showcased to other teachers and their schools. In this case, a learned society acting as the broker between school and Higher Education Institute worked well, having a broker who is respected by both sides is essential. If an excellence fellowship scheme or School Teacher Fellow scheme in another subject were contemplated, it would be sensible to start with just a few fellowships and focus on these. Having successful examples to seed the scheme appears to be most sensible.

Timing is key to ensure good candidate recruitment. In one particular year, the advertisement went out quite late, and the number of applications was lower. This is at least partly due to the fact that teachers are less likely to look at alternative career options later on in the academic year. The advertising for posts should take place at a point in the school year where potential candidates have the time to consult with their school's management teams to allow sensible planning for the disruption that removing them, often key members of the science team, will cause. Some School Teacher Fellows left their posts through a sense of loyalty to make it easier for their schools to recruit replacements. "My headteacher was not keen for me to take up the secondment at all. In the end, I took a large risk and left my permanent job ...."

\subsection{Support Structures for the Fellow}

The Excellence Fellowship scheme by default was managed by the host Higher Education Institutes in the majority of cases. Although these Higher Education Institutes provided significant resources and support (without sufficient financial support) there was still a lack of focus to the scheme and therefore projects were rarely completed and even fewer end-of-project reports were provided.

There was an orientation event for new School Teacher Fellows, the first one run by Bristol ChemLabS, to bring all the School Teacher Fellows together with their academic partners at the outset. In time the School Teacher Fellows formed their own association, providing support for new recruits and working together on projects across regions. Through the support of the Bristol ChemLabS CETL (Shallcross et al., 2013a, 2013b), in addition to the Royal Society of Chemistry, activities were arranged to support the School Teacher Fellows in addition to that received from their host institute. Once more, from a Higher Education Institute perspective, having a successful example to refer to (Bristol ChemLabS initially and then many others as the project rolled out) was helpful. It would appear that no peer-to-peer interaction was possible with the Excellence Fellowship scheme and this was a significant drawback.

In 2009 the College of School Teacher Fellows was created as a vehicle to exchange ideas and information between existing chemistry School Teacher Fellows as well as new School Teacher Fellows. The 'warts and all' day-long annual conference also invites representatives of professional bodies (such as the Royal Society and the Royal Society of Chemistry, and other interested parties).

\subsection{Liaison and Sense of Purpose}

Closer and more detailed liaison with the academic supervisors at host Higher Education Institutes should take place to ensure that successful candidates can be constructive from the outset. This may well involve pre-secondment departmental visits and should at least ensure that the School Teacher Fellow is known throughout the department, has an office, pc and e-mail address from day 1. Any suggestions made by the School Teacher Fellows, professionals in their own right, should be considered and enacted upon, at the appropriate 
level, swiftly.

\subsection{Removal of Financial Frustrations}

The financial contractual arrangements between funders and Higher Education Institutes were not always straight forward as they are between teachers and their schools. Some School Teacher Fellows were not simply taken on from the schools through secondment. One School Teacher Fellow had taken recent retirement and had to be engaged by their Higher Education Institute before the project funding could be released. Advance considerations of these potential hurdles should be considered to make the transition as smooth as possible. The School Teacher Fellows should also know what funding for projects (consumables, travel etc) are available from the outset. In the case of the Excellence Fellowship Scheme, the financial arrangements were varied and this was one of the main frustrations noted by teacher and Higher Education Institute.

\section{Why Do Some Departments Retain Their School Teacher Fellows?}

Many Higher Education Institute chemistry departments have seen the advantages that having a continued school teacher presence on the staff would have. Some School Teacher Fellows have delivered lectures to incoming students to aid transition; have taken on the roles within student recruitment and supervise students engaged in the Undergraduate Ambassador Scheme (Harrison et al, 2009c); have undertaken work on departmental or faculty outreach and may have advisory roles university-wide. With the recent requirement in the UK for researchers to show impact, there is a role for teachers to communicate the science to the wider community through articles (Appendix) and lectures set at an appropriate level.

\section{Conclusion}

The number of contributions that a School Teacher Fellow can make to a department is considerable; looking at procedures, especially in school-university transition, bringing in new teaching skills, examining congruence between school subject specifications and undergraduate courses, promotion of Chemistry and in the delivery of appropriate outreach. There are a number of lessons that can be learnt from two major projects to ease any future induction of school teachers into universities. Although there were several flaws with the design and support for the Excellence Fellowship, as described in the evaluative report, the idea of linking school teachers with Higher Education Institutes is an excellent one and with some modifications such a scheme across many disciplines could be operated with great success.

\section{Acknowledgments}

DES and TGH thank the Bristol ChemLabS CETL for their support and DES thanks the UK HEA for a National Teaching Fellowship. DR and NB thank the Universities of Southampton and Warwick and the Royal Society of Chemistry is thanked for their support of the School Teacher Fellow Scheme.

\section{References}

Andrews, C. J., Brown, R. C. D., Harrison, C. K., Read, D., \& Roach, P. L. (2010). Lecture capture: Early lessons learned and experiences shared. New Directions in the Teaching of Physical Sciences, (6), 56-60.

Boniface, J., Read, D., \& Russell, A. E. (2011). Sharing learning outcomes in chemistry teaching at HE level: beneficial or detrimental? New Directions in the Teaching of Physical Sciences, (7), 31-35.

Brown, R. C., Hinks, J. D., \& Read, D. (2012). A blended-learning approach to supporting students in organic chemistry: Methodology and outcomes. New Directions in the Teaching of Physical Sciences, (8), 33-37.

Chalkley, B. (2006). Tertiary teaching excellence: The CETLs scheme in England. New Zealander Geographer, 62, 155-157. http://dx.doi.org/10.1111/j.1745-7939.2006.00067.x

Clouder, L., Oliver, M., \& Tait, J. (2008). Embedding CETLs in a performance-oriented culture in higher education: Reflections on finding creative space. British Ed. Res. Journal, 34(5), 635-650. http://dx.doi.org/10.1080/01411920802224154

Harrison, T. G., \& Shallcross, D. E. (2010c). Towards sustainable public engagement (outreach). New Directions in the Teaching of Physical Sciences, (6), 41-46.

Harrison, T. G., Hughes, L., \& Shallcross, D. E. (2009b). Jersey schools science week: An outreach case study. New Directions in the Teaching of Physical Sciences, (4), 30-33.

Harrison T. G., \& Shallcross, D. E. (2010a). What should be expected of successful engagement between schools, colleges and universities? School Science Review, 91(35), 97-102.

Harrison, T. G., Shallcross, D. E., Shaw, A. J., Medley, M. I., \& Bell, Z. (2010b). The sweet smell of success: 
Primary pupils study fragrance science at a leading university chemistry department. Romanian Journal of Education, 1(2), 75-80.

Harrison, T. G., Shaw, A. J., Shallcross, K. L., Williams, S. J., \& Shallcross, D. E. (2010d). School-university partnerships: Lessons learned from 10 years of spectroscopy for teachers and post 16 students. New Directions in the Teaching of Physical Sciences, 6, 72-76.

Harrison, T. G., Smith, D. M., \& Shallcross, D. E. (2009c). Final year school projects: The bristol chemlabs use of the Undergraduate Ambassador Scheme. Acta Didactica Napocensia, 2(2), 35-40.

Harrison, T. G., Davey, W., \& Shallcross, D. E. (2011a). Making better and wider use of undergraduate teaching laboratories in the UK. New Directions in the Teaching of Physical Sciences, 7, 79-84.

Harrison, T. G., Heslop, W. J., Eastman, J. R., Baldwin, A. \& Shallcross, D. E. (2012a). Chemistry LabSkills: Software to support laboratory skills from school's pre-university to university foundation courses. Australian Journal of Education in Chemistry, 71, 27-29.

Harrison, T. G., Shallcross, D. E., Heslop, W. J., Eastman, J. R., \& Baldwin, A. (2009a). Transferring best practice from undergraduate practical teaching to secondary schools: The dynamic laboratory manual. Acta Didactica Napocensia, 2(1), 1-8.

Harrison, T. G., Berry, B. \& Shallcross, D. E. (2010e). A festival of contemporary science, Education in Science, 239, 11-120.

Harrison, T. G., Hanford, K. L., Cheesman, B. T., Kaur, G., Franklin, S. D., Laurain, A. M. C., ... Shallcross, D. E. (2011b). The many positive impacts of participating in outreach activities on postgraduate students. New Directions in the Teaching of Physical Sciences, 7, 13-18.

Institute of Physics (IOP) (2010). Teacher Fellowship Scheme, promoting stronger links between schools and universities. Retrieved from http://www.iop.org/education/higher_education/stem/resources/file_44400.pdf

Lambourne, R. (2007). Laboratory-based teaching and the Physics Innovations Centre for Excellence in Teaching and Learning. European Journal of Physics, 28, 29-36. http://dx.doi.org/10.1088/0143-0807/28/3/S03

Lancaster, S. J., \& Read, D. (2011). Screencasts and vignettes. Wavelength, 7(1), 40-41.

Lancaster, S. J., \& Read, D. (2013). Flipping lectures and inverting classrooms. Education in Chemistry, 49, 14-17.

Lord, P., Straw, S., Springate, I., Harland, J., \& Hart, R. (2008). Evaluation of Chemistry for Our Future Report on the first year of the evaluation (2007-2008). National Foundation for Educational Research.

Marwood, K. (2004). Evaluation of the Excellence Fellowship Awards (EFA) Pilot Scheme(Research Report RR565). York Consulting Limited.

Morales, R., \& Carmichael, P. (2007). Mapping academic collaboration networks: Perspectives from the first year of the reusable learning objects CETL. J. Universal Comp. Sci., 13(7), 1033-1041.

Niyadurupola, D. G., \& Read, D. (2008). The use of electronic voting systems to engage students in outreach activities. New Directions in the Teaching of Physical Sciences, 4, 27-29.

Norman N. C. (2007). Bristol ChemLabS Interim Evaluation Report. Retrieved from http://www.chemlabs.bris.ac.uk/InterimReviewWeb.pdf.

Page, E. M., \& Read, D. (2010). Electronic voting systems in undergraduate teaching. Education in chemistry, 47, 183-186.

Read, D. (2010a). A U.K. approach to counter declining enrolment in chemistry and related disciplines at the university level. Journal of Chemical Education, 87, 898-900. http://dx.doi.org/10.1021/ed100647s

Read, D., \& Harrison, C. K. (2010c). Review of A-level Chemistry Content. University of Southampton, Retrieved last accessed September 2013 from http://www.edshare.soton.ac.uk/5853/.

Read, D. (2010b). Happy zapping in the classroom. School Science Review, 91, 107-112.

Read, D., \& Lancaster, S. J. (2012). Unlocking video: 24/7 learning for the iPod generation. Education in Chemistry. 49, 13-16.

Robson, J. (2011). First Year Undergraduate Chemistry Laboratory Course Manual 2011-2012, Core Chemistry $1 \mathrm{~A}$ and 1B: Discovery Block 4' Learn Chemistry. Retrieved from 
http://www.rsc.org/learn-chemistry/content/filerepository/CMP/00/001/461/RSC\%20Chemistry\%20Labs\% 201A1B\%20DISCOVERY\%20Block\%204.pdf?v=1362385701412

Shallcross, D. E., Allan, N. L., Shallcross, K. L., Croker, S. J., Smith, D. M., May, P. W., ... Harrison T. G. (2011). Solving the maths problem in chemistry: The impact of a pre-university maths summer school on year 1 and year 2 Physical and Theoretical Chemistry. New Directions in the Teaching of Physical Sciences, 7, 58-62.

Shallcross, D. E., Harrison, T. G., Obey, T. M., Croker, S. J., \& Norman, N. C. (2013a). Outreach within the Bristol ChemLabS CETL (Centre for Excellence in Teaching and Learning). Higher Education Studies, 3(1), 39-49.

Shallcross, D. E., Harrison ,T. G., Shaw, A. J., Shallcross, K. L., Croker, S. J., \& Norman, N. C. (2013b). Lessons in effective practical chemistry at tertiary level: Case studies from a chemistry outreach program. Higher Education Studies, 3(5), 1-10.

Shallcross, D. E., \& Harrison, T. G. (2007a). A secondary School Teacher Fellow within a university chemistry department: the answer to problems of recruitment and transition from secondary school to University and subsequent retention? Chemistry Education Research and Practice, 8, 101-104. http://dx.doi.org/10.1039/b6rp90023b

Shallcross, D. E., \& Harrison, T. G. (2007b). The impact of School Teacher Fellows on teaching and assessment at tertiary level. New Directions in the Teaching of Physical Sciences, 3, 77-78.

Shallcross, D. E., Harrison, T. G. (2007c). Why bother taking University led Chemistry Outreach into Primary Schools? Bristol ChemLabS experience. New Directions in the Teaching of Physical Sciences, 3, 41-44.

Shallcross, D. E., Harrison, T. G., Wallington, S., \& Nicholson, H. (2006a). University and primary school links. Primary Science Review, 94, 19-22.

Shaw, A. J., Harrison, T. G., Croker, S. J., Medley, M., Sellou, L., Shallcross, K. L., ... Shallcross, D. E. (2010a). University-school partnerships: polymer chemistry days run at a university for 14-15 year olds and their impact on attitudes to science. Acta Didactica Napocensia, 3(1), 19-26.

Shaw, A. J., Harrison, T. G., Croker, S. J., Medley, M., Sellou, L., Shallcross, K. L., ... Shallcross, D. E. (2010b). University-school partnerships: on the impact on students of summer schools (for school students aged 17-18). Acta Didactica Napocensia 3(4), 35-48.

Shaw, A. J., Harrison, T. G., Medley, M., \& Shallcross, D. E. (2009). Chemistry inreach: engaging with university employees' children within a chemistry department. Acta Didactica Napocensia, 2(4), 107-112.

Shaw, A. J., Harrison, T. G., \& Shallcross, D. E. (2010c). What value has chemistry outreach by a university department to secondary schools? Acta Didactica Napocensia, 3(3), 15-23.

Shaw, A. J., Harrison, T. G., Shallcross, K. L., Williams, S. J., \& Shallcross, D. E. (2011). On the impact of the Bristol ChemLabS' Outreach program on admissions to the School of Chemistry. New Directions in the Teaching of Physical Sciences, 7, 22 -26.

SQW (2010). Summative Evaluation of the CETL Programme final report by SQW to HEFCE and DEL. Retrieved

from http://www.hefce.ac.uk/media/hefce/content/pubs/indirreports/2011/re1111evalofcetl/rd11_11.pdf

Tuah, J., Harrison, T. G., \& Shallcross, D. E. (2009). The advantages perceived by school teachers in engaging their students in university-based chemistry outreach activities. Acta Didactica Napocensia, 2(3), 31-44.

Tuah, J., Harrison, T. G., \& Shallcross, D. E. (2010). A review of the use of demonstration lectures in the promotion of positive attitudes towards, and the learning of science with reference to a 'A Pollutant's Tale', a demonstration lecture on air quality and climate change. Romanian Journal of Education, 1(3-4), 93-102.

Tunney, J. (2009). A legacy for chemistry education. New Directions in the Teaching of Physical Sciences, 5, 7-11.

Willis, A., \& Hoare, P. (2009). Chemistry of your shopping basket Chemistry for Our Future. Royal Society Chemistry.

Ashfold, M., Orr-Ewing A. J., \& Harrison, T. G. (2011). Lasers in Chemistry. Chemistry Review, 21(1), 18-21.

Badger, M. P. S., Pancost, R. D., \& Harrison, T. G. (2011). Determining how atmospheric carbon dioxide concentrations have changed during the history of the Earth. School Science Review, 93(343), 49-57. 
Cheesman, B., \& Harrison ,T. G. (2010). Silicon and silicone. Chemistry Review, 19(4), 2-5.

Eastoe, J. G., Brown, P., Grillo, I., \& Harrison, T. G. (2012). Magnetic science: Developing a new surfactant. Science in School, 25, 22-27.

Grant, A., \& Harrison, T. G. (2011). Out of thin air. Poison in the air: atmospheric carbon monoxide. Chemistry Review, 20(3), 16-20.

Harrison, T. G. (2006). Chemistry that gets right up your nose. Chemistry Review, 16(2), 2-6.

Harrison, T. G. (2012). Chemistry in its element series - silicones, Royal Society of Chemistry. Podcast. Retrieved from http://www.rsc.org/chemistryworld/podcasts.

Harrison, T. G. \& Eastoe, J. G. (2012). Breakthroughs in green chemistry: Magnetic detergents and supercritical $\mathrm{CO}_{2}$. Chemistry Review, 22(2), 10-14.

Harrison, T. G., Shallcross, D. E., \& Henshaw, S. (2006). Detecting $\mathrm{CO}_{2}$-the hunt for greenhouse-gas emissions. Chemistry Review, 15(3), 27-31.

Kaur, P., \& Harrison, T. G. (2009). Life in extreme environments. Chemistry Review, 18(3), 20-24.

Khan, A., Harrison, T. G., \& Shallcross, D. E. (2011). Out of thin air. Do ants destroy the ozone layer? Chemistry Review, 20(4), 16-18.

Mosadeghzad, Z., \& Harrison, T. G. (2009). Natural products: Chemistry and medicinal drugs. Chemistry Review, 19(1), 25-31.

Percival, C. J., Shallcross, D. E., \& Harrison, T. G. (2006). Catching the cheats - detecting drugs in sport. Chemistry Review, 15(4), 24-27.

Shallcross, D. E., \& Harrison, T. G. (2013). Radical changes in our atmosphere. Education in Chemistry, 9, 22-25.

Shallcross, D. E. (2006). Dirty air, Education in Chemistry. Royal Society of Chemistry, 43, 131-135.

Shallcross, D. E., \& Harrison, T. G. (2007). Climate change made simple. Physics Education, 42, 592-597. http://dx.doi.org/10.1088/0031-9120/42/6/005

Shallcross, D. E., \& Harrison, T. G. (2009). Hydrogen in the Earth's atmosphere. Chemistry Review, 19, 2-6.

Shallcross, D. E., \& Harrison, T. G. (2010a). Out of thin air. from volcanoes to sea salt: atmospheric sulfur. Chemistry Review, 20(1), 16-19.

Shallcross, D. E., \& Harrison, T. G. (2010b). Out of thin air. atmospheric nitrogen. Chemistry Review, 20(2), 7-9.

Shallcross, D. E., \& Harrison, T. G. (2008a). Climate change modelling in the classroom. Science in School, 9, 28-33.

Shallcross, D. E., \& Harrison, T. G. (2008b). Practical demonstrations to augment climate change lessons. Science in School, 10, 46-50.

Shallcross, D. E., Harrison, T. G., Henshaw, S. J., \& Sellou, L. (2009a). Fuelling interest: Climate change experiments. Science in School, 11, 38-43.

Shallcross, D. E., Harrison, T. G., Henshaw, S. J., \& Sellou, L. (2009c). Looking to the heavens: Climate change experiments. Science in School, 12, 38-43.

\section{Appendix}

Table A. Information on School Teacher Fellows recruited as part of the Bristol ChemLabS CETL and the RSC Schemes. *Includes those who resigned prior to taking up STF post. 


\begin{tabular}{|c|c|c|c|c|}
\hline $\begin{array}{l}\text { Academic Year } \\
\text { in Post }\end{array}$ & University Host & $\begin{array}{l}\text { Length of Time } \\
\text { Seconded* }\end{array}$ & SecondmentFunder & Notes \\
\hline $2006 / 7$ & Bristol & 1 year & Bristol ChemLabS & $\begin{array}{l}\text { Made a permanent appointment following the } \\
\text { secondment. Currently Director of Outreach and } \\
\text { Science Communicator in Residence at Bristol. }\end{array}$ \\
\hline 2007/8 (January) & Warwick & 6 months & RSC (CFOF) & $\begin{array}{l}\text { Resigned teaching post at outset of STF. } \\
\text { Now full time STF at Warwick. }\end{array}$ \\
\hline $2007 / 8$ & Southampton & 2 years & $\begin{array}{l}\text { 50\% RSC (CFOF) / } \\
50 \% \quad \text { Chemistry } \\
\text { Department } \\
\text { Southampton, } \\
\text { University }\end{array}$ & $\begin{array}{l}\text { Resigned teaching post at outset of STF. } \\
\text { Now Principal Teaching Fellow at Southampton but } \\
\text { still engaged in outreach. }\end{array}$ \\
\hline $2007 / 8$ & Nottingham & 2 years & RSC (CFOF) & $\begin{array}{l}\text { Returned to teaching in his original secondary } \\
\text { school. }\end{array}$ \\
\hline 2007 & Sheffield & 1 year & RSC (CFOF) & $\begin{array}{l}\text { Part time STF (0.2) running Sheffield's outreach } \\
\text { lab and part time chemistry teacher. (0.8) until } \\
\text { 2013. Returned to full time teacher } 2012 / 13 \text {. }\end{array}$ \\
\hline $2007 / 8$ & Birmingham & 1 Year & RSC (CFOF) & $\begin{array}{l}\text { Initially became an LEA Science Advisor then a } \\
\text { Lecturer in Science Education at Birmingham. }\end{array}$ \\
\hline $2007 / 8$ & Bath & $\begin{array}{l}\text { One term spread } \\
\text { over } 3 \text { terms }\end{array}$ & RSC (CFOF) & Returned to school teaching. \\
\hline $2007 / 8$ & Reading & One term & RSC (CFOF) & Retired \\
\hline $2007 / 8$ & $\begin{array}{l}\text { Several } \\
\text { universities in the } \\
\text { north of England }\end{array}$ & One Term & RSC (CFOF) & $\begin{array}{l}\text { Returned to school after completing a specific } \\
\text { student tracking project for the RSC. }\end{array}$ \\
\hline 2008/9 & Newcastle & I Year & RSC (C:TNG) & $\begin{array}{l}\text { Now full time at Newcastle; Chemistry Outreach } \\
\text { Officer. }\end{array}$ \\
\hline 2008/9 & $\begin{array}{l}\text { University } \\
\text { College London }\end{array}$ & 1 Year & RSC (C:TNG) & Returned to teaching \\
\hline 2008/9 & Northumbria & 1 Year & RSC (C:TNG) & $\begin{array}{l}\text { Senior Lecturer at Northumbria and engages in } \\
\text { outreach part time. }\end{array}$ \\
\hline $2009 / 10$ & Surrey & 1 Year & AstraZeneca & $\begin{array}{l}\text { Semi-retired; sessional lecturer and outreach at the } \\
\text { University of Reading. }\end{array}$ \\
\hline $2009 / 10$ & Oxford & 1 Year & AstraZeneca & Returned to school teaching. \\
\hline $2010 / 11$ & Bath & 1 Year & $\begin{array}{l}\text { RSC via HE STEM } \\
\text { initiative }\end{array}$ & Returned to school teaching part time. \\
\hline 2010/11 & Durham & 1 Year & $\begin{array}{l}\text { RSC via HE STEM } \\
\text { initiative }\end{array}$ & $\begin{array}{l}\text { Full time School Teacher Fellow at Durham with } \\
\text { academic teaching roles including first year mentor, } \\
\text { first year lab course leader and module coordinator }\end{array}$ \\
\hline
\end{tabular}


for Chemistry into Schools. Still engaged in Outreach.

2011/12

2011/12

2012/13

2013/14
Manchester 1 Year

Leicester

1Year
RSC via HE STEM Returned to school teaching.

initiative

RSC via HE STEM Returned to school teaching.

initiative

The RSC did not sponsor a STF this year.

The RSC did not sponsor a STF this year.

\section{Copyrights}

Copyright for this article is retained by the author(s), with first publication rights granted to the journal.

This is an open-access article distributed under the terms and conditions of the Creative Commons Attribution license (http://creativecommons.org/licenses/by/3.0/). 